Muiraquitã, PPGLI-UFAC, v.2, n.1, Ju1/Dez, 2013

\title{
FLECHAS COM PONTA DE AÇO: IMAGEM, POLÍTICA E HISTORIOGRAFIA INDIGENISTA NA AMAZÔNIA NAS PRIMEIRAS DÉCADAS DO SÉCULO XX ${ }^{1 *}$
}

\author{
Aldrin Moura de Figueiredo \\ Universidade Federal do Pará - Brasil
}

\section{RESUMO}

$\mathrm{O}$ artigo procura analisar a constituição de uma política indigenista na Amazônia dos anos 20. Tomando como ponto de partida algumas notícias veiculadas na imprensa da época, este trabalho pretende discutir a manipulação das imagens sobre os índios, especialmente aquelas relativas aos Urubu-Kaapor e aos Tembé que, na época estavam em processo de pacificação. Por trás dessas simples notícias estavam as polêmicas sobre o destino dos índios da região, principalmente nos debates entre o etnólogo alemão Curt Nimuendaju e o intelectual paraense Jorge Hurley e que, no fundo, ampliavam-se para uma reflexão política e uma operação historiográfica sobre identidade nacional e o futuro da formação social brasileira.

PALAVRAS-CHAVE: Curt Nimuendaju (1883-1945). Jorge Hurley (1898-1953). Política Indigenista. Operação Historiográfica. Identidade Nacional.

À memória de Expedito Arnaud (1916-1992)

Nas vésperas do Natal de 1922, a população de Belém do Pará se viu sobressaltada com a notícia de que, numa pitoresca vila de casas, chamada Vila Teta, situada à Estrada da Independência, em frente ao Museu Goeldi, existia, segundo o jornal Folha do Norte, um verdadeiro "reino da pajelança". A notícia era especialmente "estranha" porque os tais pajés foram armar sua tenda bem defronte a uma instituição conhecida, já naquela época, por dedicar-se ao estudo das antigas populações locais, especialmente os grupos indígenas. Assim, o jornal parecia insinuar que o exotismo da pajelança cabia melhor se guardada 1 * Este artigo é parte de uma pesquisa mais ampla sobre história intelectual do modernismo na Amazônia que desenvolvo na UFPA, com auxílio do CNPq. Agradeço às contribuições de Márcio Meira, Magda Ricci, Sidney Chalhoub, Priscila Faulhaber, Renato Athias, William Balée, Eneida Assis e Stephen Barris. 
no acervo do museu, longe do convívio com a civilidade da população da capital do Pará. Mas não pensemos que os pajés eram índios que teriam migrado para Belém em busca de clientes "brancos". Segundo a gazeta, por lá residiam, na verdade, "diversos negros de vida duvidosa, que à noite [reuniam-se] em sessão solene a explorar a credulidade popular por meio de danças exóticas, de defumações sufocantes e de cenas apavorantes". O problema era que, no ritual, os pretos pareciam transformar-se numa verdadeira "aldeia dos índios Urubus", na qual os participantes da sessão seguiam a preceito às antigas tradições herdadas dos índios, incorporando "botos mundiadores, ${ }^{2}$ mães d'água e outros bichos do fundo". 3

Apesar da "estranheza" da nota jornalística, as notícias sobre a existência de pajés no perímetro urbano de Belém eram corriqueiras desde os meados do século XIX. ${ }^{4}$ A diferença agora residia na imagem dos "negros" transformados em "índios" que, àquela altura parecia representar mais uma das visões refletidas no infinito caleidoscópio da pajelança urbana, sempre associada ao "passado" indígena. Examinando as notícias de jornal sobre a ocorrência de pajés nas áreas próximas ao centro da cidade, encontrei em várias ocasiões alusões a tribos consideradas hostis e criminosas, mas nunca diretamente relacionadas ao que acontecia nas sessões de pajelança. ${ }^{5}$ A referência aos índios

2 O termo "mundiar" está aqui no sentido de assombrar, magnetizar. Segundo Vicente Chermont de Miranda, diz-se do "poder que, como crê o povo, possuem as cobras e as uiaras, de entorpecer o ânimo, abolir a vontade, aniquilar o instinto de conservação, aquelas aos animais que preiam, estas aos homens cujo o amor cobiça”. Miranda, Vicente Chermont de. Glossário Paraense: coleção de vocábulos peculiares à Amazônia e especialmente à ilha do Marajó. 2a edição. Belém: Universidade Federal do Pará, 1968 [1905], p.59-65.

3 Cf. "No reino da pajelança". Folha do Norte. Belém, 22 de dezembro de 1922, p.3.

4 Figueiredo, Aldrin Moura de. "Pajés, médicos e alquimistas: uma discussão em torno de ciência e magia no Pará Oitocentista". Cadernos do CFCH, 12 (1-2): 41-54, 1993.

5 Numa pesquisa realizada nos jornais paraenses, a partir da década de 1870, encon- 
Urubu traz à cena uma ligação direta entre a representação que se tinha em relação ao passado da tradição dos pajés e um fato que ganhava, no presente, grande atenção por parte da imprensa.

Estamos diante de um exemplo bastante evidente da cultura visual da época veiculada pela imprensa escrita. Estava em jogo a imagem da tribo, como sociedade primitiva, manifesta em rituais arcaicos - um conceito que continua intocado no que poderíamos chamar no imaginário popular, com todos os problemas que esta categoria de análise possa ter. ${ }^{6} \mathrm{O}$ fato era que, os tais índios Urubu, matrizes da imagem de desordem atribuída aos negros da Vila Teta, estiveram muito em evidência durante as décadas de 1910 e 1920. Estes índios, na verdade eram os $\mathrm{Ka}$ 'apor, também conhecidos pelos brancos da fronteira do Pará-Maranhão como Urubu, desde pelo menos o final do século XVIII, com uma simbologia ligada à pintura corporal, aos ornamentos plumários e ao estigma de carniceiros. Apesar dessa longa história de contatos, esses índios só começaram de fato a ser "pacificados" em

tramos muitas referências às tribos hostis da Amazônia. Na década de 1890, os índios Canela ficaram muito famosos por suas "correrias" na região bragantina, próxima ao município de Ourém, no Pará. Cf. Pinheiro, José de Andrade. "Os índios de Ourem". In: Ensaios religiosos e litterarios. Paris: Guillard, Aillaud \& Cie., 1898, pp.267-274. Nas primeiras décadas do século XX, a região fronteiriça do Pará como o Maranhão começa a ganhar destaque, com as notícias sobre os Tembé, os Timbira, os Guajajará e, principalmente, os Urubu. A imprensa de Belém, além da perspectiva policial de controle da "selvageria", sugere que, assim como as penas e os maracás utilizados na pajelança urbana de Belém, as histórias dos índios ficariam melhor guardadas no Museu Paraense. Desde o final do século XIX, os intelectuais da região, enfatizam uma retórica civilizadora bem ao modelo do folclorismo oitocentista europeu, no qual o lugar de arcos, penas e flechas, "coisas de índio" é no museu. É um discurso de enclausuramento do selvagem, ou melhor, de controle da barbárie por uma prática civilizadora. Cf. Figueiredo, Aldrin Moura de. "Pajés, médicos e alquimistas... e, idem, A cidade dos encantados: pajelanças, feitiçarias e religiões afro-brasileiras na Amazônia, 1870-1950. Belém: Edufpa, 2009.

6 Cf. Fried, Morton. The notion of tribe. Menlo Park: Cummings, 1975 e Gregory, Robert. Tribes and tribal: origin, use, and future of the concept. Studies Tribes Tribals, 1(1): 1-5, 2003, p.1. 


\section{1, num processo que se estendeu até $1928,{ }^{7}$ quando os primeiros membros do grupo contataram "amistosamente" funcionários do SPI ${ }^{8}$}

7 Segundo Darcy Ribeiro “o nome 'urubus' é naturalmente designação brasileira e data do tempo em que constituíam a tribo mais aguerrida do Pará, que mantinha em pé de guerra todo o alto curso do rio Gurupi. Eles se designam como Kaapor, que significa aproximidamente "moradores da mata"'. Ribeiro, Darcy. Uirá vai ao encontro de Maíra: as experiências de um índio que saiu à procura de Deus". Anhembí, 26(76): 21-35, 1957, p.23. Estes índios habitam a região fronteiriça entre o Pará e o Maranhão. Por volta dos anos 20 ainda eram arredios e mantinham contatos apenas com os descendentes de quilombolas que habitavam áreas próximas aos rios Turiaçu, Gurupi e Paranaiba, além de outros grupos indígenas que habitavam nas proximidades, entre eles, os Timbira, os Tembé e os Guajajara. Sobre a "genealogia" dos Urubu, ver Nimuendaju,Curt. "The Turiwara and Aruã". In: Handbook of South American Indians. vol.3. Washington, 1948, p.193 e Ribeiro, Darcy. Diários Índios: os Urubus-Kaapor. São Paulo: Companhia das Letras, 1996, p.216; sobre os primeiros contatos durante e imediatamente após a pacificação, ver Hurley, Jorge. Nos Sertões do Gurupy. Belém: Officinas Graphicas do Instituto Lauro Sodré, 1928; Lopes, Raimundo. "Os Índios Urubu: resenha de resultados da viagem ao Gurupy (1930) e do estudo comparativo". Boletim do Museu Nacional, (8): 127-129, 1932; Idem, "Os tupis do Gurupy". Actas del XXV Congreso Internacional de Americanistas, La Plata, 1932, (1): 139-171, 1934. Para um conhecimento mais detalhado da organização social do grupo, vide Ribeiro, Darcy. "Os índios Urubus: ciclo anual das atividades de subsistência de uma tribo da floresta tropical". Anais do XXXI Congresso Internacional de Americanistas, São Paulo, 1955, (1): 127-157, 1955, e especialmente Diários Índios: os Urubus-Kaapor, 1996; um amplo relato etnográfico da situação dos índios está em Huxley, Francis. Affable savages: an anthropologist among the Urubu indians of Brazil. London: Hart-Davis, 1956; para uma visão geral dos grupos indígenas da "área Pindaré-Gurupi", vide Galvão, Eduardo. "Áreas culturais indígenas no Brasil, 1900-1959". In Encontro de sociedades: índios e brancos no Brasil. Rio de Janeiro: Paz e Terra, 1979, pp.193-228.

8 Criado em 20 de julho de 1910, o Serviço de Proteção aos Índios e Localização de Trabalhadores Nacionais, como o próprio nome sugere, procurou desenvolver uma ação combinada que pudesse atrair os índios para viver em colônias agrícolas, adquirindo, desse modo, hábitos mais sedentários. Quatro anos depois, no entanto, com o fracasso dessa investida o governo acabou percebendo a especificidade do trabalho indigenista, o que levou o Serviço a dedicar-se exclusivamente a essa questão. Nas décadas seguintes uma das tarefas mais importantes para a instituição foi a pacificação e o assistencialismo. Em relação aos Urubu-Kaapor, o SPI elaborou um plano de pesquisas para ser realizado no período pós-pacificação, do qual participaram antropólogos e indigenistas. Cf. Ribeiro, Darcy. "Atividades científicas da secção de estudos do Serviço de Proteção aos Índios". 
no posto de atração da ilha de Canindé-Açu, no alto Gurupi, entre o Pará e o Maranhão. Em 1911, o SPI organizou um grupo que levava presentes em forma de ferramentas de aço e apetrechos do gênero, rio Turiaçu acima, na esperança de "atrair" os índios. Numa dessas expedições, guerreiros que espreitavam o grupo atiraram no maxilar de um voluntário, motivo que fez com que os esforços fossem abandonados. Por outro caminho, ao longo do alto rio Gurupi, agentes do SPI também tentaram, em vão, pacificá-los entre 1911 e 1912.

Três anos mais tarde, até 1917, o SPI não teve recursos financeiros para os esforços de pacificação dos Ka'apor e os conflitos se acalmaram. Em 1918, após essa trégua, ataques dos índios motivados pela busca de ferramentas de aço tiveram lugar respectivamente na bacia do rio Guamá e em Bragança, perto da costa atlântica do Pará. Os Ka'apor também foram agredidos por grupos de brasileiros irritados com a presença indígena nas proximidades das colônias. ${ }^{9} \mathrm{Um}$ agente de telégrafo no Maranhão, que organizou invasões às aldeias Ka'apor, espetou as cabeças de índios mortos próximo dos postos de telégrafo entre os lagos Viana e o rio Gurupi. Por isso mesmo, os índios atacaram o Posto Indígena Gonçalves Dias, do rio Pindaré, que era de serventia aos índios Guajajara. Os relatos do encarregado do posto informam que, durante o ataque, "os índios bravios a nada atendiam e investiam com furor". ${ }^{10}$ Os anos seguintes de 1919 e 1920 foram de total insegurança no vale do Gurupi devido aos ataques desses mesmos índios. Não à toa os Urubu eram lembrados na imprensa de Belém como índios sanguinários que usavam flechas com pontas de aço, com as quais cometiam "correrias" entre os colonos das vilas agrícolas da

Sociologia, XIII (4): 5-37, 1959.

9 Balée, William. Footprints of the Forest: Kaapor Etnobotany: The historical ecology of plants utilization by an amazonian people. New York: Columbia University Press, 1994.

10 Ribeiro, Darcy. Os índios e a civilização. São Paulo: Círculo do Livro, 1985, p.178. 
vizinhança. Em 1920, o jornal O Estado do Pará publicou informações enviadas à redação por um morador do igarapé Jepuy, na colônia Benjamin Constant, na Cidade de Bragança, no interior do Estado, enfatizando que os "selvagens estavam em pé-de-guerra com os brancos". E acrescenta:

Os índios Urubus, que anualmente, nos meses de setembro a outubro, passam neste município em correrias, atacando os nossos lavradores e assassinando-os, já este anos visitaram. No dia 14 do corrente atacaram uma casa na colônia (...). [Na ocasião] os selvagens praticaram 4 mortes (...). Após o ataque, os Urubus fizeram completo saque na casa atacada. Os filhos dos assassinados, no momento do ataque, que teve lugar pela manhã e ao voltarem ao meio dia encontraram o desolador quadro (...). O prefeito de polícia compareceu ao local fazendo a autopsia dos cadáveres, apreendendo as flechas e remetendo-as ao Sr. Desembargador e Chefe de Polícia. ${ }^{11}$

O antropólogo Darcy Ribeiro, que dedicou muitos de seus trabalhos aos Urubu Kaapor, conta que por volta de 1920, a situação de insegurança em todo o vale do Gurupi se agravara de tal modo que as autoridades do Maranhão e do Pará foram instadas a decretar o estado de sítio em toda a região, para garantir a vida e a propriedade dos moradores civilizados. Acrescenta ainda que "expedições punitivas contra as aldeias indígenas eram também periodicamente organizadas", se referindo especialmente a uma que ocorreu em 1922, ano em que a notícia da pajelança da vila Teta circulou em Belém. Essa expedição foi levantada "por um deputado estadual e pelo prefeito de Peralva, composta de 56 homens fortemente armados". Dirigiram-se ao Alto Turi e após 6 dias de marcha, assaltaram uma aldeia Kaapor e mataram no trajeto dois homens, o que alertou os demais, possibilitando a fuga. Na madrugada seguinte, reforçados por índios de outra aldeia, os fugitivos cercaram os expedicionários, "despejando sobre estes sa-

11 Ver O Estado do Pará. Belém, 20 de outubro de 1920, p.2. Cf. Figueiredo, Aldrin Moura de. A cidade dos encantados, 2009, p.255, nota. 
raivadas de flechas". Provocando nova fuga dos índios "quando já tinham esgotado quase toda a munição, os invasores queimaram a aldeia e destruíram as roças, antes de regressar". ${ }^{12}$

No início dos anos 50, o mesmo Darcy Ribeiro pesquisando na área ainda ouviu relatos de pessoas que presenciaram os ataques dos Urubu. Segundo o antropólogo, "a eficiência dos ataques, movidos muitas vezes pelo desejo de saque - já que os índios utilizavam metal para as pontas de flechas -, levou a população local a acreditar que os ka'apor eram dirigidos por criminosos evadidos dos presídios do Maranhão e do Pará e mesmo de Caiena e por negros remanescentes de antigos quilombos". ${ }^{13}$ Foi uma década muito difícil para os moradores da região: os índios irritados com a presença dos brancos nas proximidades das suas terras e os colonos com medo dos ataques, revidando quando era possível. A situação só começou, de fato, a se acalmar entre anos de 1926 e 1928, quando se concluiu o processo de "pacificação" dos Urubu, depois que ambos os lados já tinham experimentado violência suficiente.

Segundo William Balée, o saber tradicional Ka'apor construiu o mito de um homem Ka'apor, denominado Pa'i ("padre"), que "pacificou" (mu-katu) os brasileiros no Posto Canindé do SPI, na região do Gurupi. Por seu turno, os relatórios do Serviço de Proteção aos Índios registram que foram os seus esforços em oferecer ferramentas de aço e outros bens sob tapiris que teriam levado os Ka'apor a buscar a paz. Em 15 de dezembro de 1928, 94 índios Ka'apor visitaram o Posto Canindé do SPI. Mais ou menos ao mesmo tempo, guerreiros Ka'apor aproximaram-se da cidade de Alto Turi, junto ao rio Turiaçu, com as suas flechas apontadas para baixo, em sinal das intenções amigáveis.

12 Ribeiro, Darcy. “A pacificação dos Índios Urubu Kaapor”. In: A política indigenista brasileira. Rio de Janeiro: Ministério da Agricultura, 1962, p.85.

13 Ribeiro, Darcy. Os índios e a civilização, 1985, p.162, grifos meus. 
As guerras dos índios Ka'apor haviam terminado, mas certamente não de forma definitiva. ${ }^{14}$

Em 1919, o Governo do Estado do Pará enviou à região dos rios Pindaré e Gurupi uma expedição chefiada pelo Dr. Jorge Hurley com o objetivo de "sindicar as causas das incursões das tribos do alto Irituia, alto Guamá e alto Gurupi, promovendo por todos os meios a pacificação das referidas tribos". ${ }^{15}$ Jorge Hurley, além de juiz de direito, era um intelectual respeitado no Pará. No início da década de 20 transitava entre os literatos modernistas paraenses, colaborando regularmente na revista Belém Nova, órgão fundado em $1923^{16}$. Profundamente interessado pela pesquisa histórica, Hurley era interlocutor de alguns dos mais respeitados intelectuais da região, como era o caso de Raimundo Morais e José Carvalho. Desde essa época, Hurley também era interessado em literatura e folclore, escrevendo artigos tematizando as tradições e os costumes amazônicos. ${ }^{17}$

14 Balée, William. Footprints of the Forest, 1994.

15 Cf. "Instrucções" assinadas pelo Sr. Eladio Lima, Secretário Geral do Estado Pará, em 4 de dezembro de 1919, publicadas no Diario Official do Estado do Pará, em 12 de dezembro de 1919, p.3.

16 Figueiredo, Aldrin Moura de. Letras insulares: leituras e formas da história no modernismo brasileiro". In: Chalhoub, S. \& Pereira, L (orgs.). A história contada: capítulos de história social da literatura. Rio de Janeiro: Nova Fronteira, 1998, pp.301-331; Idem, A cidade dos encantados, 2009.

17 Em toda a década de 20, Hurley vai marcar uma forte presença na intelectualidade paraense, escrevendo sobre assuntos muito diversificados entre si, misturando os campos etnográfico, histórico e folclórico no contexto do movimento modernista local. Cf. Hurley, Jorge. "Prehistoria americana". Revista do Instituto Histórico e Geográfico do Pará, VI(6): 1-100, 1931; Idem, "Dialeto Urubu, amerabas da raça tupy do Gurupy". Revista do Instituto Histórico e Geográfico do Pará, VII (7): 245-249, 1932; Idem, “Os mysterios de jurupary”. Revista do Instituto Historico e Geografico do Pará, XIX(9): 93-113, 1934. Para uma análise de contexto intelectual na obra de Hurley, vide Ricci, Magda. "Folclore, literatura e história no Estado Novo: a trajetória de Henrique Jorge Hurley". In: Fontes, Edilza \& Bezerra Neto, José Maia (0rgs). Diálogos ente história, literatura e memória. Belém: Paka-Tatu, 2007, p.309-328. 
A expedição ao Gurupi foi, neste sentido, ponta de lança para que o literato ampliasse suas preocupações com os estudos folclóricos e etnográficos. No próprio relatório da expedição ao Gurupi, Hurley levantou uma tese "original" sobre a natureza dos índios sanguinários. Para ele, sob "o título feio e voraz de índios urubus", existia "uma terrível e temível mescla de selvagens guajajaras com os criminosos dos sertões do Maranhão". ${ }^{18} \mathrm{O}$ interessante é que Darcy Ribeiro, ainda nos anos 50, anotou uma "lenda", corrente tanto em Belém como no Gurupi à época da pacificação dos Urubu, que "descrevia esses índios como mestiços dos Timbira e negros quilombolas". ${ }^{19}$ Eram histórias como a do preto George Amir, um francês fugido de Caiena que teria vivido entre os Urubu, como uma espécie de chefe deles. Relatos sobre as façanhas de Amir chegaram a ganhar na imprensa de Belém, em 1920. ${ }^{20}$

Essas histórias mostram o quanto eram largas e complexas as influências exercidas nas representações sobre a identidade dos índios amazônicos, demonstradas aqui pela situação dos Urubu. Essas representações e manipulações de identidade foram fundamentais para solidificação dos discursos sobre a realidade das ditas "reminiscências" tribais que ainda teimavam em resistir em plena capital do Pará. Por isso mesmo a imagem do índio que vivia edenicamente na floresta, durante a década de 1920, dividia o espaço da imprensa com a imagem do selvagem que sobrevivia simbolicamente nos negros e nos pajés de Belém. Ainda estavam em jogo as antigas imagens ritualísticas da pajelança misturadas às notícias de índios que provocavam desordens pelo interior do Estado, assaltando as pequenas cidades e vilarejos, por meio das lutas sangrentas com os colonos.

18 Hurley, Jorge. Nos Sertões do Gurupy. Belém: Officinas Graphicas do Instituto Lauro Sodré, 1928, p.33.

19 Ribeiro, Darcy. Os índios e a civilização, 1985, p.162.

20 O Estado do Pará. Belém, 26 de fevereiro de 1920, p.2. 
Intelectuais como Jorge Hurley não estavam, por seu lado, presos a gabinetes de trabalho. Seguindo um impulso da política governamental de civilizar o povo, paradoxalmente abraçavam ao mesmo tempo a perspectiva intelectual dos anos 20 e 30, baseada no modernismo regionalista de valorizar as características culturais brasileiras, argumentando sobre uma civilização do trópico. ${ }^{21} \mathrm{O}$ pano de fundo das discussões continuava sendo a necessidade de desvendar o sentido "original" do país, suas especificidades, enfim. A noção recorrente da formação étnica e social da nação através das três raças formadoras continuava presente, mesmo que sob um novo significado. A malfadada "mestiçagem urubu", de que falava Jorge Hurley, resultava da escória étnica e cultural da Amazônia: índios selvagens, descendentes de negros fujões e criminosos urbanos, dentre os quais jamais se pensaria existir algum jovem branco. Enquanto isso, na cidade de Belém, os pajés e seus ritos macabros passavam por dar o melhor sentido a esse tipo racial criminoso e degenerado. ${ }^{22}$

Esse debate sobre a situação da religião dos pajés misturava-se cada vez mais, à época, com as discussões sobre a política indigenista

21 Para uma visão bastante completa da produção literária da época, vide Azevedo, José Eustachio de. Literatura Paraense. Belém: Tip. de A Palavra, 1922; para um aprofundamento das questões políticas e literárias envoltas no modernismo paraense, vide Figueiredo (1998). Nos anos 30, também ganha notoriedade na imprensa as sínteses de interpretação da realidade brasileira, baseadas em fundamentos históricos e sociológicos. São especialmente citados Casa Grande \& Senzala, de Gilberto Freyre e Raizes do Brasil, de Sérgio Buarque de Holanda. Cf. Figueiredo, Aldrin Moura de. O anti-herói e a cobra-grande: fronteiras literárias do modernismo na Amazônia. In: Fares, Josebel Akel (Org.). Diversidade cultural: temas e enfoques. Belém: Unama, 2006, v. 2, p.189-206.

22 Em 1922, o historiador Ignacio Moura escreveu um artigo no qual se propunha discutir o legado das raças formadoras da população paraense. Nesse texto, apesar de incorporar a idéia das três raças formadoras, acaba prevalecendo a referência ao índio como o responsável pelo "caráter" da gente local. Cf. Moura (1934). Vide também Cruz, Ernesto. "Ethnologia Indígena". Revista do Instituto Histórico Geográfico do Pará, XX(10): 23$38,1936$. 
brasileira, pois era de se pensar que preservando o índio se estaria garantindo o germe dessas crenças por muito mais tempo. Um momento especial desses confrontos intelectuais foi vivido em Belém em 1920. Neste ano, assumia a Chefia da Seção Etnográfica do Museu Paraense Emílio Goeldi o etnólogo alemão Curt Nimuendajú que, desde 1913, mantinha residência mais ou menos fixa no Pará. Vale notar que, em 1922, quando pajelança da Vila Teta, ali defronte no Museu Goeldi, Nimuendaju traçava sua política em relação os índios do Gurupi, especialmente aos já pacificados. Em quase todos esses aspectos, o etnólogo germânico opunha-se firmemente à política indígena idealizada por Jorge Hurley, especialmente quanto ao destino e à conservação da cultura original dos grupos. O confronto ficou mais claro quando veio à baila o assunto dos índios da região do Gurupi, na qual habitavam os Tembé, os Timbira, os Guajajara e os famosos Urubu. Hurley queria a todo custo "civilizar" o mais rápido possível essas populações, procurando dar condições para que o índio se transformasse num "brasileiro". A idéia era "matar" a figura do índio e construir sobre ela a do civilizado. Quanto às tradições, seriam registradas no momento da conquista, da pacificação e conservadas sob a forma de etnografia e folclore. Assim ninguém teria que enfrentar índios bravos e sanguinários, ao mesmo tempo em que se mataria o embrião das crenças pagãs, guardando apenas os registros do passado. ${ }^{23}$

Nimuendajú tinha uma visão bastante distinta. Nos anos de 1914 e 1915, portanto antes de Hurley, o etnólogo esteve em contato com os índios do Gurupi. ${ }^{24}$ Trabalhando para o Serviço de Proteção ao Índio,

23 Hurley, Jorge. "Prehistoria americana". Revista do Instituto Histórico e Geográfico do Pará, VI(6): 1-100, 1931.

24 Para uma visão bastante completa das atividades de Curt Nimendajú na Amazônia, vide Nimuendaju, Curt. "Sagen der Tembé-Indianer (Pará und Maranhão)". Zeitschrift für Ethnologie, (47): 281-301, 1915; Idem, The Eastern Timbira. Los Angeles: University of California Press, 1946; Nunes Pereira, Manoel. Curt Nimuendajú: síntese de uma vida e 
visitou os Tembé, os Timbira e os temidos Urubu, estudando a língua e recolhendo narrativas míticas sobre a criação do mundo, seguindo o percurso que já havia iniciado com os Apapokuva-Guarani. ${ }^{25}$ Mas além da pesquisa etnológica, Nimuendaju quando de seu retorno do Gurupi, aproveitou para denunciar o assassinato dos índios Canela, estabelecidos em Travessia, no Oeste do Maranhão, cujo autor fora absolvido pela "justiça popular" (Nunes Pereira 1946: 25). Além dessa denúncia envolvendo os Canela, grupo que voltaria a visitar ${ }^{26} \mathrm{o}$ etnólogo começava armar sua polêmica com Jorge Hurley, o enviado do governo do Pará para pacificar os índios do Pindaré-Gurupi. Em carta ao Diretor do SPI, datada de 1920, Curt Nimuendajú dizia que os índios daquela região figuravam "entre os mais ou menos intactos", ${ }^{27}$ por isso era necessária toda atenção daquele órgão e dos indigenistas. Atestava, assim, sua indignação com a proposta de Jorge Hurley em trazer os índios Tembé do Gurupi para morar com os Tembé do Guamá, que viviam mais próximos do contato com a "civilização".

As poucas aldeazinhas do alto Guamã (sic), teatro da ação redentora do Sr. Hurly (sic), não merecem importância comparado com as do

de uma obra. Belém: Museu Paraense Emílio Goeldi, 1946, onde existe um apêndice cronológico das viagens, tribos pesquisadas e obras publicadas pelo etnólogo. Cf. também Amoroso Marta Rosa. "Nimuendajú às voltas com a história". Revista de Antropologia, 44(2):173-18, 2001. Agradeço ainda a generosidade com que, em 1993, depois de uma aula especial do curso lato sensu em Teoria Antropológica, no Laboratório de Antropologia Arthur Napoleão Figueiredo, na UFPa, fui atendido por Expedito Arnaud, que chegou a conhecer Nimuendajú no início da década de 1940.

25 Nimuendaju, Curt. "Die Sagen von der Erschaffung und Vernichtung der Welt als Grundlagen der Religion der Apapokuva-Guarani”. Zeitschrift für Etnologie, (46): 284403, 1914.

26 Nimuendaju, Curt. "The social structure of the Rankókamekra 'Canella"”. American Anthropologist, 40 (1): 51-74, 1939.

27 Carta de Curt Nimuendajú ao Ilmo. Sr. Dr. Luiz Bueno Horta Barbosa, diretor do Serviço de Proteção ao Índio. Belém, 23 de Julho de 1920, publicada em Nimuendajú, Curt. Etnografia e Indigenismo: sobre os Kaingang, Ofaié-Xavante e os Índios do Pará. Campinas: Editora da Unicamp, 1993, p.141-154. 
Gurupi. Se fosse pela minha cabeça eu convidaria todos os Tembé do Guamã para se mudarem para o Gurupi, como em 1914 já se mudou um bando da aldeia de São Pedro. Isto sim convinha, mas não a mudança dos do Gurupi para o Guamã, como Hurly quer - se ele sabe o que é que ele quer. ${ }^{28}$

Além dessa visão teatralizada da "ação redentora" de Hurley, Nimuedaju deixava claro que seus critérios, longe de se apoiar rigidamente em suportes ou critérios de identidade étnica de fundo biológico, suas iniciativas buscavam a preservação cultural dos grupos indígenas, com uma forte leitura utópica de resguardar aquelas sociedades em sua "pureza" e "autenticidade". Esta iniciativa em manter os índios o quanto mais afastados do contato com a dita civilização era o maior interesse de Nimuendajú. Neste ponto as visões de Hurley e Nimuendajú pareciam até semelhantes, afinal ambos defendiam que os contatos culturais eram destrutivos para uma das culturas em situação de contato. A diferença, entretanto, é que Hurley considerava que o índio só teria a ganhar com a "civilização" nacional, mas o branco tinha algo a perder contaminando-se com a herança dos "selvagens". Nimuendajú, porém, apostava que o índio sairia destruído desse contato, no rastro da exploração e dos desmandos do "branco". ${ }^{29}$ O etnólogo germânico, no entanto, que vivia e conhecia o dia a dia da cidade de Belém, tinha convicção que mesmo destruindo os índios jamais se acabaria com a pajelança, pois esta permanecia ativa em pleno centro urbano das capitais amazônicas. Noutra carta, enviada sete anos depois, ao diretor do Museu Goeldi e também etnólogo Dr. Carlos Estevão de Oliveira, Nimuendajú, que estava pesquisando na

28 Nimuendaju, Etnografia e Indigenismo, 1993, p.145, o primeiro grifo é de Nimuendajú, o segundo é meu.

29 Para uma leitura contrária ao pensamento de Nimuendajú e do SPI, vide Hurley, Jorge. "Prol cathechese do aborígene brasileiro. O serviço de proteção aos 'índios' do Pará e talvez no Brasil, por sua inefficiencia, é pura ficção". Revista do Instituto Histórico e Geográfico do Pará, VII (7): 223-227, 1932. 
região do alto Rio Negro, no Estado do Amazonas, desabafava diante dos desmandos cometidos contra a religião e os costumes dos índios.

... a decadência da cultura indígena é espantosa; todos para isto se coligam: os colombianos que, espezinhando e vitimando o índio pela maneira mais bárbara, lhe tiram o último vestígio de brio e consciência; os brasileiros, com a sua mania de civilizar índios, com a idéia de fazer deles eleitores e com sua prática de arrumar-lhes nas costas um débito e cobrá-lo depois ou por bem ou por mal (quando não enveredam pela mesma brutalidade dos colombianos); os padres salesianos, que na sua intolerância extirpam sistematicamente tudo o que difere da 'civilização cristã', proibindo a construção de malocas, o uso do caxiri ${ }^{30}$, do trocano ${ }^{31}$, dos enfeites de penas e de pedras, as danças e o culto do Yurupari ${ }^{32}$. Bestas! Em três séculos, padres e frades, as centenas não conseguiram banir o pajé do perímetro da capital de Belém sequer; o que eles conseguiram no Uaupés $^{33}$ senão a criação de um bando de hipócritas? Mas como eles apresentam as suas medidas como vontade do governo, os índios se submetem.... ${ }^{34}$

30 Bebida alcoólica preparada a partir da massa de mandioca desfeita n'água, passando depois por um processo de fermentação. Essa bebida foi incorporada por caboclos do interior da Amazônia. Cf. O verbete "caxiri” em Miranda, Glossário Paraense, 1968 [1905], p.22.

31 Do tupi toro 'kana. Tambor feito de um tronco de árvore utilizado por vários grupos indígenas sul-americanos, especialmente para se comunicarem com outras aldeias.

32 Sobre o Yurupari (ou Jurupari), vide a nota 145 da primeira parte. Vale a pena consultar o trabalho Guilherme Saake sobre a crença do Jurupari entre os índios Baniwa, habitantes do Içana, visinhos do grupo Uanana visitados por Nimuendajú em 1927. Cf. Saake, Guilherme. "O mito do Jurupari entre os Baniwa do Rio Içana". In: Schaden, Egon. Leituras de Etnologia Brasileira. São Paulo: Cia. Editora Nacional, 1976, pp.277385. Uma opinião contrária a de Nimuendaju sobre a preservação do Jurupari, está em Hurley, Jorge. "Os mysterios de jurupary". Revista do Instituto Historico e Geografico do Pará, XIX(9): 93-113, 1934.

33 Rio localizado próximo à fronteira do Brasil com a Colômbia, no Estado do Amazonas, onde Nimuendajú esteve com os Uanana.

34 Carta de Curt Nimuendajú ao Dr. Carlos Estevão de Oliveira, diretor do Museu Paraense Emílio Goeldi. São Gabriel da Cachoeira, alto Rio Negro, Estado do Amazonas, 1927, publicada recentemente pela associação dos índios da região, num boletim informativo sugestivamente intitulado "Triste memória do passado recente". Cf. WAYURI. n.31. São Gabriel da Cachoeira, AM, jul-ago, 1995, p.8. 
A lucidez do etnólogo impressionava especialmente pela ampla visão que conseguia ter sobre o assunto. Nimuendajú teve a grande virtude de se considerar uma pessoa comum e não uma grande autoridade em etnologia. Segundo Expedito Arnaud, saudoso etnólogo do Museu Goeldi, Nimuendajú quando estava em Belém participava da boêmia da cidade, andava à noite pela Condor, metido com amigas prostitutas $^{35}$ e companheiros de cerveja. Com isso, sabia muito sobre o "submundo" da cidade; conhecia muito bem as pajelanças da Pedreira, Marco da Légua e obviamente da Vila Teta, em frente à instituição de pesquisa da qual foi um dos diretores entre 1920 e 1921, por isso sentia-se autorizado a falar sobre os destinos da religião dos pajés da cidade e dos pajés das tribos. No relatório final da viagem ao alto Rio Negro, apresentado ao SPI, datado de Belém do Pará, em 27 de setembro daquele mesmo ano de 1927, Nimuendajú reafirma as conclusões esboçadas na carta a Carlos Estevão.

Milhares e milhares de religiosos doutrinaram durante três séculos a população de Belém; há tempos desapareceram dos arredores da capital os últimos índios da região. Mas antes de morrer eles legaram aos mestiços, seus sucessores, o pajé, que, de maracá em punho, ainda hoje, dentro da capital, resiste com vantagem contra o padre e o agente de polícia. ${ }^{36}$

35 A Condor é o nome de um tradicional bairro boêmio de Belém localizado na zona portuária da cidade. Por volta dos anos 20 e 30 já era considerado área de meretrício. Quanto ao conhecimento de Nimuendajú sobre as condições do local, no Reconhecimento dos rios Içana, Ayari e Uaupés, um relatório apresentado ao SPI do Amazonas e Acre, sobre sua viagem ao rio Negro, o etnólogo estabelece uma comparação entre a maloca indígena uma casa de prostituta, para demonstrar o quanto era equivocada a leitura dos religiosos em relação aos costumes dos índios: "Quanto ao prejuízo que a convivência de diversas famílias na maloca, dizem acarretar é simplesmente falso; devido à rigorosa exogamia Não existem relações amorosas entre os filhos da mesma maloca; no mais as prostitutas das nossas cidades, por exemplo, vivem em cubículos muito bem separados, mas por isso são mais moralizadas que as índias da maloca”. Nimuendajú, Curt. Textos Indigenistas: relatórios, monografias, cartas. São Paulo: Loyola, 1982, p.190.

36 Nimuendajú, Curt. Textos Indigenistas: relatórios, monografias, cartas. São Paulo: Loyola, 1982, p.189. 
No entremeio do estudo, o desafogo do etnólogo. As palavras de Nimuendaju guardam os significados de uma longa história da política indigenista no Brasil, e em especial na Amazônia, que foi sendo construída na experiência desses intelectuais com o diálogo constante e a presença viva de seus "objetos de pesquisa". Seu olhar atento a respeito da "sobrevivência" dos pajés e da pajelança, na Belém dos anos 20, reafirmava sua opinião a respeito dos contatos "civilizatórios" com os índios durante todo o século XIX. Se o SPI não havia sido a melhor solução para o problema indígena, muito mais malévolo foi o controle exercido pela Igreja Católica através das missões religiosas. A postura humanista apregoada pelo SPI lhe foi de muito mais valia do qualquer convívio com missionários, ainda mais quando tinha que entrar em desavenças (o que não era raro) com a população dos pequenos vilarejos próximos às aldeias. Nesses lugares a população, mais do que nunca, via os índios como animais disfarçados sob uma aparência humana. A carta do morador do Igarapé Jepuy, sobre os ataques dos Urubu, é bem reveladora neste sentido.

Esta encruzilhada de debates ganhava a imprensa e, com isso, despertava o interesse de diversos grupos sociais voltados para o destino dos índios brasileiros, demostrando com isso que a política indigenista não foi obra de uma meia dúzia de letrados iluminados que defiram univocamente o melhor lugar para as sociedades tribais. É certo que se nesta arena existiu algum vencedor, este não saiu de modo algum ileso dessas contendas. Prova disso, foi o maior fôlego adquirido na posterior luta pela demarcação das terras indígenas e, com isso, pelo direito dos índios de opinar sobre as diretrizes políticas que lhes diziam respeito, contrariando definitivamente o que defendia Jorge Hurley quando este detratava com a atuação do SPI. ${ }^{37}$ Só para dar um

37 Hurley, Jorge. "Prol cathechese do aborígene brasileiro. O serviço de proteção aos 'índios' do Pará e talvez no Brasil, por sua inefficiencia, é pura ficção". Revista do Instituto Histórico e Geográfico do Pará, VII (7): 223-227, 1932. 
exemplo, os Tembé do Rio Guamá, tidos por Hurley, em 1919, como em franco processo de "civilização" e por isso capazes de convencer seus parentes do Gurupi a fazer o mesmo, hoje são considerados índios "insubordinados". É o caso de lembrarmos o aconteceu há poucos anos, quando estes mesmos Tembé prenderam um avião e de alguns funcionários da Funai, até que suas reivindicações fossem atendidas.

Com esta análise quero enfatizar que, diferentemente de algumas abordagens clássicas como as do próprio Darcy Ribeiro ou mesmo outras mais recentes, à maneira de José Mauro Gagliardi, a constituição das políticas indigenistas no Brasil não resultou de uma visão unilateral de um grupo ou de uma autoridade governamental, mas ao contrário disto como um campo de tensões e mediações no espaço político. Nestas relações, os diferentes sujeitos sociais envolvidos seguiam na mor parte das vezes seus interesses específicos, articulando relações e conflitos de classe e/ou de tensões étnico-culturais entre a chamada sociedade nacional e os grupos indígenas. ${ }^{38}$ No caso em tela, a opinião de Hurley, por exemplo, buscava paulatinamente incorporar os índios ao universo da "civilização" brasileira. Nitidamente baseado em critérios de identidade étnica que passavam pelo campo biológico, como era comum na sua época ${ }^{39}$, Hurley insistia na definitiva transformação dos índios em "brasileiros", matriculando-os em escolas técnicas, ensinando-lhes um ofício, para assim tentar diluir socialmente a presença do grupo étnico, definindo seu lugar social e de classe na sociedade brasileira. ${ }^{40}$

38 Ribeiro, Darcy. “A pacificação dos Índios Urubu Kaapor”. In: A política indigenista brasileira. Rio de Janeiro: Ministério da Agricultura, 1962, p.82-95; Gagliardi, José Mauro. O indígena e a república. São Paulo: Hucitec/Edusp, 1989.

39 Cunha, Manuela Carneiro da. "Parecer sobre critérios de identidade étnica". In Antropologia do Brasil: mito, história, etnicidade. 2a ed. São Paulo: Brasiliense, 1987, pp.113-117.

40 Hurley, Jorge. Nos Sertões do Gurupy. Belém: Officinas Graphicas do Instituto Lauro Sodré, 1928. 
Nimuendaju, por outro lado, procurava inserir-se politicamente neste debate tentando influir "cientificamente" na opção por manter os índios o mais distante possível do contato com os brancos. Cartas e relatórios foram escritos amiúde a fim de demonstrar o desastre histórico dos confrontos étnicos e culturais entre índios e brancos. Apoiado em figuras de prestígio político, tanto no cenário local como nos meios científicos, como era o caso do Dr. Carlos Estevão de Oliveira, diretor do Museu Goeldi, Nimuendaju levava a termo um trabalho que já foi confundido como uma espécie de "missão redentora", mas que, no fundo, tinha interesses acadêmicos muito claros. ${ }^{41}$ Por seu turno, os Urubu e os Tembé agenciavam seus interesses em manter-se como "diferentes", embora dialogando e negociando de diversos modos com os "brancos" e os "brasileiros", fosse através das famosas "correrias" e saques ou por meio de alianças com os grupos ou pessoas, como os negros remanescentes dos quilombos da região do Pindaré-Gurupi ou com figuras legendárias com a do francês George Amir que, fugitivo de Caiena, chegou a "chefe" de índios.

41 Cf. Baldus, Herbert. "Curt Nimuendaju”. Sociologia, 8(1): 45-52, 1946; Nunes Pereira, Manoel. Curt Nimuendajú: síntese de uma vida e de uma obra. Belém: Museu Paraense Emílio Goeldi, 1946;

1946; Métraux, Alfred. "Curt Nimuendaju (1883-1945)". Journal de la Société des Américanistes de Paris, N.S., (39): 250-251, 1950; Schaden, Egon. "A obra científica de Curt Nimuendajú". Revista del Ateneo Paraguayo, II (1): 27-29, 1966; idem, "Notas sobre a vida e a obra de Curt Nimuedaju". Revista de Antropologia, 15-16: 77-89, 1967-1968; Viveiros de Castro, Eduardo B. "Curt Nimuendaju: 104 mitos indígenas nunca publicados. Revista do Patrimônio Histórico e Artístico Nacional, (21): 64-111, 1986; Idem, "Nimuendaju e os Guarani". In Curt Nimuendaju. As lendas da criação e destruição do mundo como fundamentos da religião dos Apapocúva-Guarani. São Paulo: Hucitec/ Edusp. pp.xvii-xxxviii, 1987; Figueiredo, Aldrin Moura de. A cidade dos encantados: pajelanças, feitiçarias e religiões afro-brasileiras na Amazônia, 1870-1950. Belém: Edufpa, 2009. Para uma leitura das redes intelectuais amazônicas, especialmente no campo da antropologia, ver Faulhaber, Priscila. "Nos varadouros das representações: redes etnográficas na Amazônia do início do século XX”. Revista de Antropologia, 40(2):101-143, 1997. 
Está claro que nessa história da política indigenista na Amazônia, os índios definitivamente atuaram como "sujeitos". Agentes desse processo histórico, os intelectuais também partilharam na constituição de um campo de debates e tensões políticas, mediadas por seus interesses em definir o "lugar" e o "papel" de cada sujeito neste campo que entrecruza conflitos e alianças ${ }^{42}$. Alargando a perspectiva de "campo", sobejamente discutida por Bourdieu ${ }^{43}$, pretendo com esta análise demonstrar que, na constituição das políticas indigenistas, os diferentes sujeitos sociais, ao contrário do que sugere o autor francês lutaram por construir uma autonomia de ação política dentro de seus campos de atuação, mesmo que esta autonomia fosse relativa. É o que acontece com Hurley e Nimuendaju, pois ambos representavam instâncias políticas do governo brasileiro - Hurley em nome do próprio governo do Pará e Nimuendaju ao Museu Goeldi, instituição ligada à mesma administração paraense, e ao SPI -, porém defendiam idéias muito distintas. As próprias instituições são, muitas vezes, pensadas como "aparelhos de poder governamentalizado instituído", ora para "gerir a relação entre os povos indígenas, distintos grupos sociais e demais aparelhos de poder", como poderia ser o caso do SPI, ${ }^{44}$ ou para dar suporte científico para a atuação desses órgãos estatais, como seria o caso do Museu Goeldi ou do Museu Nacional. ${ }^{45} \mathrm{Na}$ verdade, porém,

42 Figueiredo, Aldrin Moura de. A cidade dos encantados, 2009, p.213-17.

43 Bourdieu, Pierre. "Champ intellectuel et projet créateur". Les temps moderns, (246): 865-906, 1966; Idem, "Champ du pouvoir, champ intellectuel et habitus de classe". Scolies, (1): 7-26, 1971.

44 Lima, Antonio C. S. de. O governo dos índios sob a gestão do SPI". In Manuela Carneiro da Cunha (org.). História dos índios no Brasil. São Paulo: Companhia das Letras/ Secretaria Municipal de Cultura/Fapesp, 1992. p.155.

45 Lima, Antonio C. S. de. Aos fetichistas, ordem e progresso: um estudo do campo indegenista no seu estado de formação. Dissertação de mestrado, MN/PPGAS/UFRJ, 1985, 2v.; Idem, "Sobre indigenismo, autoritarismo e nacionalidade: considerações sobre a constituição do discurso e da prática da proteção fraternal na Primeira República". In: Oliveira Filho, João Pacheco de. (org.). Sociedades indígenas e indigenismo no Brasil. 
ao lado da fachada institucional aparentemente homogênea, com instituições que "pensam" os destinos e as políticas cientificas ${ }^{46}$ existem os indivíduos, como sujeitos sociais, que agem politicamente elaborando e executando seus projetos e, ao mesmo tempo, articulando diferentes interesses.

Assim, nessa história da constituição das políticas indigenistas, os intelectuais representaram muito mais do que um projeto institucional. Atuaram numa arena de tensões e conflitos, tanto como os executores e mentores das políticas de atuação, como sujeitos que pensaram e articularam interpretações mais amplas sobre os destinos da sociedade brasileira, da qual os índios, de um modo ou de outro, deveriam fazer parte. Por seu turno, até que esses índios, como é o caso dos Urubu ou dos Tembé, pudessem aprender, com sua experiência de contato com os "brancos", a negociar nesse campo que ia do diálogo político à guerra e ao genocídio, foi fundamental o acirramento desses conflitos em torno de uma resposta que pudesse garantir o direito dos índios em manter dignamente sua liberdade e domínio sobre sua própria casa, que, ao que parece, ainda está, apesar de seus esforços, longe de uma conclusão.

DARTS WITH STEEL TIP: PICTURE, INDIGENOUS POLITICS AND HISTORIOGRAPHY IN THE AMAZON IN THE EARLY DECADES OF THE TWENTIETH CENTURY

\section{ABSTRACT}

This paper discusses the constitution of Indigenism in Amazonia in the twenties. Using various news articles from that period as departure point, it looks at the way

Rio de Janeiro: UFRJ; São Paulo: Marco Zero, 1987. pp. 149-204; Idem, “Os museus de história natural e a construção do indigenismo: notas para uma sociologia das relações entre campo intelectual e campo político no Brasil". Comunicação MN/PPGAS, (13): 4-85, 1989.

46 Douglas, Mary. How Instituitions Think. Syracuse: Syracuse University Press, 1986. 
images on Indians were manipulated, in particular the ones portraying the UrubuKaapor and Tembé who were then going through a pacification process. Beyond those simple news lied the dispute on the fate of the Indians in the region whose main actors were german ethnographer Curt Nimuendaju and intelectual Jorge Hurley from Para. Through this polemic, both engaged in a political reflexion and in the definition of an historiography for the ongoing construction of Brazil's national identity and the future of its social formation.

KEYWORDS: Curt Nimuendaju (1883-1945). Jorge Hurley (1898-1953). Indigenous Policy. Historiographical Operation. National Identity.

\section{REFERÊNCIAS}

BOROFSKY, R. Making history: Pukapukan and anthropological constructions of knowledge. Cambridge: Cambrigde University Press, 1987. BALÉE, W. Análise preliminar do inventário florestal e a etnobotânica Ka'apor. Boletim do Museu Paraense Emílio Goeldi, Botânica, 2(2): 141218, 1986.

BALÉE, W. Footprints of the Forest: Kaapor Etnobotany: The historical ecology of plants utilization by an amazonian people. New York: Columbia University Press, 1994.

BALÉE, W. Biodiversidade e os índios amazônicos, In: CASTRO, Eduardo V. de \& CUNHA, Manuela Carneiro da (orgs.). Amazônia: etnologia e história indígena. São Paulo: NHII-USP, 1993b, pp.385-393.

CUNHA, M. C. Indigenous transformation of Amazonian Forest: an example from Maranhão, Brazil. L'Homme, 33: 126-128, 1996.

CERTEAU, M. L'operation historique, In: Le Goff, Jacques \& Nora, Pierre. (dir.) Faire de l'Histoire: nouveaux problèmes. Paris: Gallimard, 1974. p.3-41.

CERTEAU, M. L'operation historiographique, In: L'écriture de l'histoire. Paris: Gallimard, 1975. p.66-110.

FAULHABER, P. Nos varadouros das representações: redes etnográficas na Amazônia do início do século XX. Revista de Antropologia, 40(2):101-143, 1997.

FAULHABER, P. Letras insulares: leituras e formas da história no moder- 
nismo brasileiro, In: CHALHOUB, S. \& PEREIRA, L (orgs.). A história contada: capítulos de história social da literatura. Rio de Janeiro: Nova Fronteira, 1998, pp.301-331.

FAULHABER, P. Eternos modernos: uma história social da arte e da literatura na Amazônia, 1908-1929. Tese de doutorado em história. Campinas: IFCH-UNICAMP, $2001 \mathrm{a}$.

FAULHABER, P. Parque da cidade, museu da nação: nacionalismo, modernismo e instituições científicas na Amazônia, 1930-1945, In: Faulhaber, P. \& Toledo, P. M. de. (Orgs.). Conhecimento \& fronteira: história da ciência na Amazônia. Belém: MPEG, 2001b, pp.181-204.

FAULHABER, P. A cidade dos encantados: pajelanças, feitiçarias e religiões afro-brasileiras na Amazônia, 1870-1950. Belém: Edufpa, 2009.

FIGUEIREDO, A. M. Pajés, médicos e alquimistas: uma discussão em torno de ciência e magia no Pará Oitocentista, In: Cadernos do CFCH, 12, 1993, 41-54.

FRIED, M. The notion of tribe. Menlo Park: Cummings, 1975.

FRIEDLANDER, J. Being indian in Hueyapan: a study of forced indentity in contemporary Mexico. New York: St. Martin's Press, 1975.

GAGLIARDI, J. M. O indígena e a república. São Paulo: Hucitec/Edusp, 1989.

GEERTZ, C. Being there: anthopology and the scene of writing, In Works and lives: the anthropologist as author. Stanford: Stanford University Press, 1988.

GREGORY, R. Tribes and tribal: origin, use, and future of the concept. Studies Tribes Tribals, 1(1): 1-5, 2003.

HURLEY, J. Nos Sertões do Gurupy. Belém: Officinas Graphicas do Instituto Lauro Sodré, 1928.

HURLEY, J. "Prehistoria americana". Revista do Instituto Histórico e Geográfico do Pará, VI (6): 1-100, 1931.

HURLEY, J. Dialeto Urubu, amerabas da raça tupy do Gurupy. Revista do Instituto Histórico e Geográfico do Pará, VII (7): 245-249, 1932a.

HURLEY, J. Prol cathechese do aborígene brasileiro. O serviço de prote- 
ção aos "índios" do Pará e talvez no Brasil, por sua inefficiencia, é pura ficção. Revista do Instituto Histórico e Geográfico do Pará, VII (7): 223-227, $1932 b$.

HURLEY, J. Os mysterios de jurupary. Revista do Instituto Historico e Geografico do Pará, XIX (9): 93-113, 1934.

HUXLEY, F. Affable savages: an anthropologist among the Urubu indians of Brazil. London: Hart-Davis, 1956.

LIMA, A. C. S. Aos fetichistas, ordem e progresso: um estudo do campo indegenista no seu estado de formação. Dissertação de mestrado, MN/ PPGAS/UFRJ, 1985, 2v.

LIMA, A. C. S. Sobre indigenismo, autoritarismo e nacionalidade: considerações sobre a constituição do discurso e da prática da proteção fraternal na Primeira República, In: OLIVEIRA FILHO, J. P. (org.). Sociedades indígenas e indigenismo no Brasil. Rio de Janeiro: UFRJ; São Paulo: Marco Zero, 1987. pp. 149-204.

LIMA, A. C. S. Os museus de história natural e a construção do indigenismo: notas para uma sociologia das relações entre campo intelectual e campo político no Brasil. Comunicação MN/PPGAS, (13): 4-85, 1989. LIMA, A. C. S. O governo dos índios sob a gestão do SPI, In: CUNHA, M. C. (org.). História dos índios no Brasil. São Paulo: Companhia das Letras/Secretaria Municipal de Cultura/Fapesp, 1992. pp. 155-172.

LIMA, A. C. S. Da guerra de conquista ao poder tutelar: elementos sobre a relação entre estado nacional e povos indígenas no Brasil republicano, In: AZEVEDO, F. L. N. de \& MONTEIRO, J. M. (Orgs). Confronto de culturas: conquista, resistência, transformação. Rio de Janeiro: Expressão e Cultura; São Paulo: Edusp, 1997. pp.345-367.

LOPES, R. Os Índios Urubu: resenha de resultados da viagem ao Gurupy (1930) e do estudo comparativo, In: Boletim do Museu Nacional, (8): 127-129, 1932.

LOPES, R. Os tupis do Gurupy, In: Actas del XXV Congreso Internacional de Americanistas, La Plata, 1932, (1): 139-171, 1934.

MÉTRAUX, A. Curt Nimuendaju (1883-1945), In: Journal de la Société 
des Américanistes de Paris, N.S., (39): 250-251, 1950.

MIRANDA, V. C. Glossário Paraense: coleção de vocábulos peculiares à Amazônia e especialmente à Ilha do Marajó. $2^{\mathrm{a}}$ edição. Belém: Universidade Federal do Pará, 1968 [1905].

MOURA, I. Etnographia Histórica do Pará, In: Revista do Instituto Histórico e Geographico do Pará, XIX. 7-19, 1934.

NIMUENDAJÚ, C. Die Sagen von der Erschaffung und Vernichtung der Welt als Grundlagen der Religion der Apapokuva-Guarani. Zeitschrift für Etnologie, (46): 284-403, 1914.

NIMUENDAJÚ, C. Sagen der Tembé-Indianer (Pará und Maranhão). Zeitschrift für Ethnologie, (47): 281-301, 1915.

NIMUENDAJÚ, C. The social structure of the Rankókamekra "Canella". American Anthropologist, 40 (1): 51-74, 1939.

NIMUENDAJU,, C. The Eastern Timbira. Los Angeles: University of California Press, 1946.

NIMUENDAJÚ, C. Textos Indigenistas: relatórios, monografias, cartas. São Paulo: Loyola, 1982.

NIMUENDAJÚ, C. Etnografia e Indigenismo: sobre os Kaingang, Ofaié -Xavante e os Índios do Pará. Campinas: Editora da Unicamp, 1993.

NIMUENDAJÚ, C. Nimongaraí. Mana 7 (2):143-149, 2001.

NIMUENDAJÚ, C. Excursões pela Amazônia. In: Revista de Antropologia, 44 (2): 189-200, 2001.

RIBEIRO, D. Atividades científicas da secção de estudos do Serviço de Proteção aos Índios. Sociologia, XIII (4): 5-37, 1959.

RIBEIRO, D. Os índios Urubus: ciclo anual das atividades de subsistência de uma tribo da floresta tropical. In: Anais do XXXI Congresso Internacional de Americanistas, São Paulo, 1955, (1): 127-157, 1955.

RIBEIRO, D. A arte plumária dos índios Kaapor. Rio de Janeiro: Civilização Brasileira, 1957.

RIBEIRO, D. Uirá vai ao encontro de Maíra: as experiências de um índio que saiu à procura de Deus. Anhembí, 26(76): 21-35, 1957.

RIBEIRO, D. A pacificação dos Índios Urubu Kaapor. In: A política indi- 
genista brasileira. Rio de Janeiro: Ministério da Agricultura, 1962, p.8295.

RIBEIRO, D. Os índios e a civilização. São Paulo: Círculo do Livro, 1985.

RIBEIRO, D. Diários Î́ndios: os Urubus-Kaapor. São Paulo: Companhia das Letras, 1996.

STOCKING JR., G. Race, culture and evolution: essays in the history of anthropology. Chicago: University of Chicago Press, 1968.

ZEBBA, S. Making Uirapuru: a musical quest in the Brazilian Rain Forest. Boletim do Museu Paraense Emílio Goeldi. Série Ciencias Humunas, 5(1): 173-184, 2010. 